\title{
Phenology and vegetative growth of the fig tree cv "Roxo de Valinhos" under a drastic pruning system
}

\author{
Thamyres Yara Lima Evangelista ${ }^{1,2 *}$, Assussena Carvalho Miranda ${ }^{1,2}$, \\ Francisco Almir Campelo Monte Junior,2, Emanuela Sousa Cavalcante', Cibele Divino Aguiar,3, \\ Gustavo Alves Pereira'
}

${ }^{1}$ Agronomic Engineering, Federal University of Piauí, Teresina, Brazil, '2Foundation for Research Support of Piauí (FAPEPI), Teresina, Brazil, ${ }^{3}$ Coordination of Improvement of Higher Education Personnel (CAPES), Brasília, Brazil

\section{A B S TR A C T}

The phenological adaptability and growth of the fig tree (Ficus carica L.) was observed periodically in the Brazilian semi-arid, State of Piauí, Brazil. The study was done using in 46 plants of the fig tree cv "Roxo de Valinhos", in Bom Jesus, Piauí in the period from April to August of 2018. The meteorological elements associated with phenology were: air temperature, relative humidity, precipitation, and photoperiod. The results revealed significant relations between the phenology, growth, and climatic conditions showing promising answers for the cultivation of the fig tree cv "Roxo de Valinhos", in the semi-arid region of Piauí.

Keywords: Ficus carica L.; Fig; Piauí; Pruning; Semi-arid

\section{INTRODUCTION}

In the past few years the cultivation of the fig tree (Ficus carica L.) was a restricted practice in the South, and Southeast regions of Brazil, due to the climatic limitations. However, in the recent years, cultivation in tropical regions has proved to be a viable alternative, due to good adaptation and productivity of plants (Lopes et al., 2018), and the low climatic variations characterized by distinct seasons that vary according to the rainfall (Rodrigues et al., 2012).

Fig tree is characterized by dormancy during winter, the period in which plants restrict or cease their growth allowing their survival to hydric stress and low temperatures (Celedonio et al., 2013; Freitas et al., 2015; Silva et al., 2017). However, dormancy induced by hibernal cold can be broken by reduced vegetative activity from a drastic pruning being able to anticipate the fruit production and harvest (Micheloud et al., 2018).

Fig tree is characterized by dormancy during winter, the period in which plants restrict or cease their growth allowing their survival to hydric stress and low temperatures
(Celedonio et al., 2013; Freitas et al., 2015; Silva et al., 2017). However, dormancy induced by hibernal cold can be broken by reduced vegetative activity from a drastic pruning (Micheloud et al., 2018), with complete elimination of the canopy formed in the previous cycle, stimulating the growth of the meristematic and cambial cells (Taiz et al., 2017), and consequently promoting the formation of new branches of production (Silva et al., 2017).

In the tropical regions weather, pruning management maintains medium-sized plants, facilitating crop management, conditioning flowering and can anticipate the production and harvest of fruits with yields exceeding 15,000 kg ha ${ }^{-1}$ (Micheloud et al. 2018). As well as acting in the phytosanitary control of the rust of the fig tree (Cerotelium fici) (Mezzalira et al., 2015).

Edaphoclimatic situation of the Northeast region guarantees of agronomic development of species of temperate and subtropical climate (Rodrigues et al., 2012) like the cultures of persimmon (Lopes et al., 2013a; 2013b), apple tree (Miranda et al., 2015), and pear tree (Oliveira et al., 2015). In this approach, information is

\footnotetext{
*Corresponding author:

Thamyres Yara Lima Evangelista, Federal University of Piauí, Center for Agrarian Sciences. UFPI Campus Professor Cinobelina Elvas, Coordination of the Graduate Program in Agricultural Sciences. BR 135, km 03, S/N Neighborhood Planalto Horizonte 64900-000 - Bom Jesus/PI - Brasil, Phone: (89) 99904-7252. E-mail: thamyresevangelista@outlook.com
} 
sought regarding the adaptation of the fig tree in order to maximize the production and commercialization of the fruits in the off-season.

Studies on the adaptation of the fig tree submitted to drastic pruning become an essential, for the development of crops in warm regions may provide extemporaneous crops with high-quality fruits, making it a good income option, as observed by Celedonio et al., 2013; Freitas et al., 2015; Silva et al., 2016; 2017.

The objective of this study was tocharacterize the adaptability phenological, and growth of the fig tree cv "Roxo de Valinhos," under a drastic pruning system in the Brazilian semi-arid region, Piauí State, Brazil.

\section{MATERIAL AND METHODS}

\section{Study area description}

The study was conducted in April 2018 in an experimental orchard of the Group of Studies in Fruticulture (FRUTAGRO), Federal University of Piauí Campus Professor Cinobelina Elvas (UFPI/CPCE), Bom Jesus, Piauí, Brazil (0904'59.9" S, and $44^{\circ} 19^{\prime} 36.8^{\prime \prime} \mathrm{W}, 287 \mathrm{~m}$ above sea level).

The region climate classified as Aw (tropical wet) with dry winter season (Köppen and Geiger, 1928). The climatic data during the experiment were obtained by the Brazilian Institute of Meteorology (INMET, 2019, and are shown in Fig. 1. The average annual rainfall was $1,200 \mathrm{~mm}$, with an annual mean temperature of $26.6^{\circ} \mathrm{C}$. The soil was classified as Yellow Latosol (Santos, 2013), and its physical and chemical characteristics are shown in Table 1.

\section{Conducting the experiment}

It were used 46 plants of fig tree cv "Roxo de Valinhos" 1 year old spaced $2 \times 1.5 \mathrm{~m}$. The first pruning was performed

Table 1: Chemical and physical characteristics of the soil at 0-20 cm depth

\begin{tabular}{|c|c|}
\hline Soil characteristic & Value $0-20(\mathrm{~cm})$ \\
\hline $\mathrm{pH}$ (in water) & 6.4 \\
\hline $\mathrm{Ca}^{2+}\left(\mathrm{cmolc} . \mathrm{dm}^{-3}\right)^{\mathrm{b}}$ & 3.0 \\
\hline $\mathrm{H}^{+} \mathrm{Al}^{3+}\left(\mathrm{cmolc} . \mathrm{dm}^{-3}\right)$ & 3.96 \\
\hline $\mathrm{K}^{+}\left(\mathrm{cmolc} . \mathrm{dm}^{-3}\right)$ & 0.38 \\
\hline $\mathrm{Mg}^{2+}\left(\mathrm{cmolc} \cdot \mathrm{dm}^{-3}\right)^{\mathrm{b}}$ & 0.54 \\
\hline$P\left(m g \cdot d m^{-3}\right)^{a}$ & 17.58 \\
\hline $\mathrm{Fe}\left(\mathrm{mg} \cdot \mathrm{dm}^{-3}\right)$ & 58.90 \\
\hline $\operatorname{Mn}\left(\mathrm{mg} \cdot \mathrm{dm}^{-3}\right)$ & 18.19 \\
\hline $\mathrm{Zn}\left(\mathrm{mg} \cdot \mathrm{dm}^{-3}\right)$ & 1.46 \\
\hline Clay $\left(\mathrm{g} \cdot \mathrm{kg}^{-1}\right)$ & 266 \\
\hline Silt $\left(\mathrm{g} \cdot \mathrm{kg}^{-1}\right)$ & 31 \\
\hline Sand $\left(\mathrm{g} \cdot \mathrm{kg}^{-1}\right)$ & 703 \\
\hline Organic matter (\%) & 12.5 \\
\hline
\end{tabular}

aP: Resin 1; ${ }^{\mathrm{b}} \mathrm{Ca}, \mathrm{Mg}$, and $\mathrm{Al}: \mathrm{KCl} 1 \mathrm{M}$ extractor when the plants were 7-month old, pruning the apex of the main branch to $50 \mathrm{~cm}$ of the soil, and leading with three structural branches throughout the vegetative cycle, leading the branches with $40-\mathrm{cm}$ long, for the development of branches of new production (Silva et al., 2017).

On April 7, 2018, the drastic pruning was done, after pruning, the branches were brushstroked with fungicide as a preventive to avoid the emergence of diseases. Fertilization was carried out 30 days after pruning (DAP) according to the soil analysis (Table 1), incorporated superficially in a $40-\mathrm{cm}$ band around the plants spaced at $1.50 \mathrm{~m}$, and in a range of $40 \mathrm{~cm}$, for each side of the line, in plots with $0.75 \mathrm{~m}$ between the plants.

Subsequent fertilizations were permormed with foliar micronutrients every 60 days, being the first one at the time of sprouting. Irrigation system consisted on drippers spaced $30 \mathrm{~cm}$ in irrigation line per planting line, offering $40 \mathrm{~L}$ of water per plant per day. Weed management was carried with manual weeding. The phytosanitary treatments for the control of rust (copper oxychloride and tebuconazole) and of mites (abamectin and sulfur) were applied as needed.

Evaluations started four DAP when all the plants already had sprouted. It were selected two productive branches by structural branch (Silva et al., 2017), totaling six branches per plant, and 276 branches per area. The sprouting evaluation was carried out daily, while growth evaluation was performed every 2 weeks.

\section{Evaluations}

For the phenological adaptability evaluations of the plants (Fig. 1), was used the methodology of Silva et al. (2017). In relation to the vegetative development were evaluated, the number of buds sprouted per plant, length and branch diameter, number of leaves, nodes, and secondary branches. Productive yield assessments were, flowering buds and vegetative buds, percentage of flowering and fruiting rate. According to the recommendations for plant growth analysis (Oliveira et al., 2002). All measuring were carried out fortnightly until the first harvest 119 DAP.

\section{Statistical analysis}

Descriptive statistics were used to analyze the adaptability of fig trees cv "Roxo de Valinhos". Quantitative variables were evaluated through the regression analysis using the R Core Team program (2018).

\section{RESULTS AND DISCUSSION}

At 119 DAP, tree figs showed synchronism at the development exposing an arrangement of temporal 


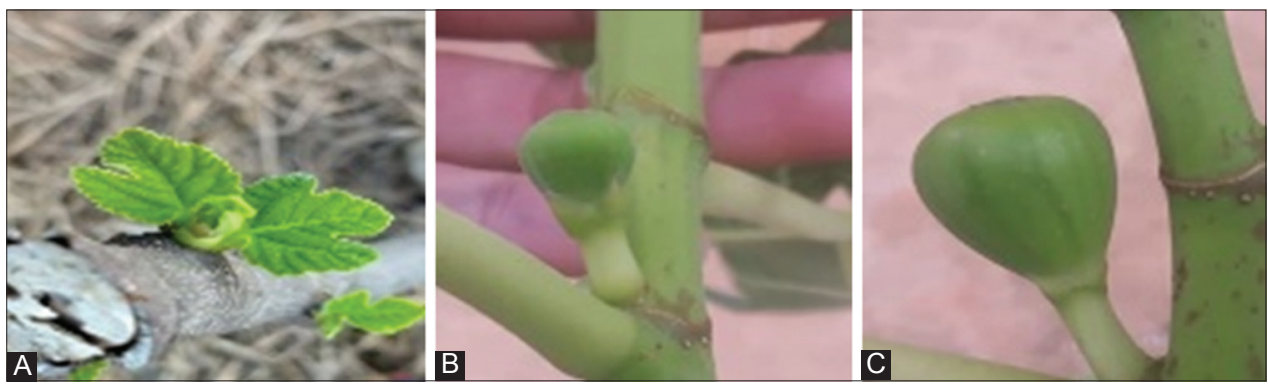

Fig 1. Stages of evaluation, budding, flowering and fruiting, respectively.

phenological patterns related to well-defined dry seasons (Fig. 2). At the beginning of the phenological observations, in April 2018, all the plants showed two distinct phenotypes of regular form, sprouting, and mature leaves. According to Caetano et al. (2012), these factors may be related to the hot climate of the region, causing the early opening of the buds, and alteration in the other phases.

The average period for plants to present six shoots was four DAP (Table 2), reaching stability on the $14^{\text {th }}$ day (Fig. 3A). In May 2018, sprouting was no longer verified and the leaves already presented a total growth. The average budding time until the first development of the infructescence was 45 DAP with fruiting heterogeneous, divergence at maturation, and fruiting stages.

In the semi-arid region, plant phenological patterns tend to go along the seasonal change of precipitation, since the availability of water acts as the main inducer of sprouting and flowering. Thus, plant submission to stress caused a direct change in flowering and early fruiting, altering the plant cycle (Bergamaschi, 2007).

The average period of appearance of the fruit until the beginning of ripening, color change, was 34 DAP. The increase in temperature after pruning imply the photoassimilates flow, causing the growth of vegetative, and reproductive buds (Fig. 2B), and the development of infructescence until maturation (Souza et al., 2009).

The period of maturation to the beginning of harvest (fully purple fruits), was $36 \mathrm{DAP}$ (Table 1). According to Chiang et al. (2018), some fig tree species show a delay in maturation stage, while others anticipate the final stage of development changing color rapidly due to the climatic conditions.

In the tropical region, the supply of fruits of the cv "Roxo de Valinhos" resembles other species of Ficus. Gaaliche et al. (2017), evaluated the agro-phenological behavior of some Ficus species and found an average of 38 days. Most of the plant species, besides the genus Ficus present seasonal reproductive phenologies (Morellato et al., 2013),
Table 2: Phenological behavior of the fig tree cv "Roxo de Valinhos," Bom Jesus Piauí

\begin{tabular}{lccc}
\hline $\begin{array}{l}\text { Phenological } \\
\text { characteristic }\end{array}$ & Date & NDAPa $^{\text {N }}$ & $\begin{array}{c}\text { Number } \\
\text { of days }\end{array}$ \\
\hline Pruning & $04 / 07 / 2018$ & - & - \\
Sprouting & $04 / 11 / 2018$ & 4 & 4 \\
Starting flowering & $05 / 26 / 2018$ & 49 & 45 \\
$\begin{array}{l}\text { Beginning of } \\
\text { maturation of fruits }\end{array}$ & $06 / 30 / 2018$ & 83 & 34 \\
$\begin{array}{l}\text { Beginning of harvest } \\
\text { Cycle }\end{array}$ & $08 / 06 / 2018$ & 119 & 36 \\
\hline${ }^{a}$ NDAP = number of days after pruning & & 119 \\
\hline
\end{tabular}

producing figs continuously in the proportion of fruiting (Bain et al., 2014; Zhao et al., 2014).

The genus Ficus exerts strong protoginia, the female sex organs mature before the maleones, causing selective pressure to maintain fig production throughout the year (Chiang et al., 2018. The duration of the cycle found in the survey, 119 DAP, was lower than those found by Silva et al. (2017), who observed the phenology and production of the fig tree cv "Roxo de Valinhos" in western PotiguarMossoró, $\mathrm{RN}$, with an average temperature of $27^{\circ} \mathrm{C}$ and $68.9 \%$ relative humidity.

Despite the similar climatic characteristics, the period between pruning and harvesting was 130 DAP for plants pruned on July 24, 2015, evidencing the precocity of the productive cycle of the fig tree cr "Roxo de Valinhos" in hot climatic conditions (Silva et al., 2017). The studies of adaptability in hot climate regions have contributed significantly to the knowledge of the mechanisms of subtropical species growth, allowing to analyze changes in the phenological pattern of plants.

In terms of vegetative development observed, a standardization in all aspects evaluated. The length of the branch showed polynomial growth with a constant increase of $0.28 \mathrm{~cm}$ day- 1 , and a mean of $68.2 \mathrm{~cm}$ along 119 DAP (Fig. 3C). Silva et al. (2017) evaluated the phenology and yield of the fig tree cv "Roxo de Valinhos" at 130 DAP, and found the value of $122 \mathrm{~cm}$ at the field level. Celedonio et al. (2013) studied the growth of fig trees in three growth 
environments, and obtained a length of $110.50 \mathrm{~cm}$ with 90 days of the field.

The diameter of the branch presented linear growth with a constant increase of $0.14 \mathrm{~cm}$ day- 1 , and a mean of $1.8 \mathrm{~cm}$ of branching along the 119 DAP (Fig. 3D). Similar data were observed by Silva et al. (2017), with $2.11 \mathrm{~cm}$ of average in 130 DAP. These results demonstrate the good adaptability and rusticity of the fig tree cv "Roxo de Valinhos" to different environments.

Regarding the number of leaves and the number of nodes per branch (Fig. 3E), there was a polynomial increase of both, with values of 36.6 leaves and 23.9 nodes per branch at 119 DAP. At 110 DAP, the leaves showed stability. Celedonio et al. (2013), evaluated fig trees in the region

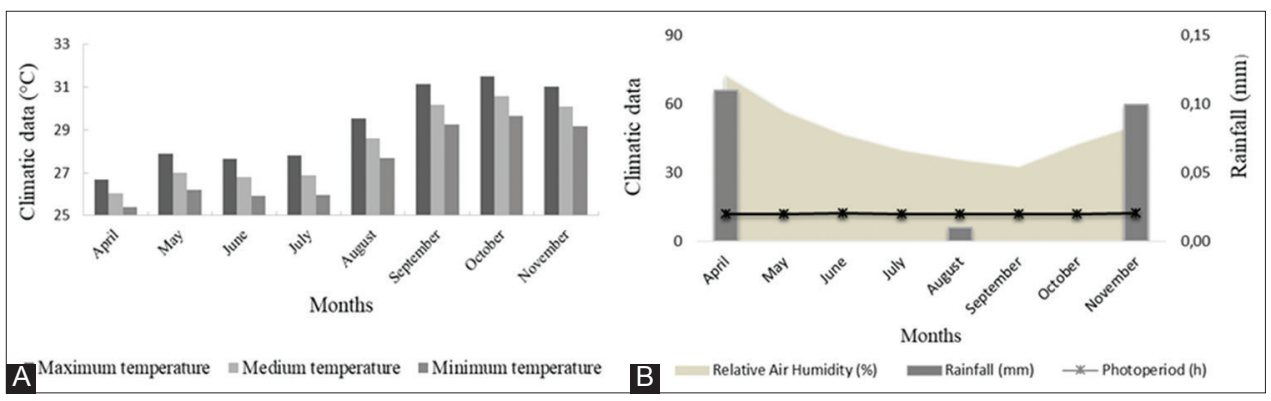

Fig 2. Climatic data: (A) temperature maximum, medium, and minimum and (B) relative air humidity (\%), rainfall (mm), and photoperiod (h).

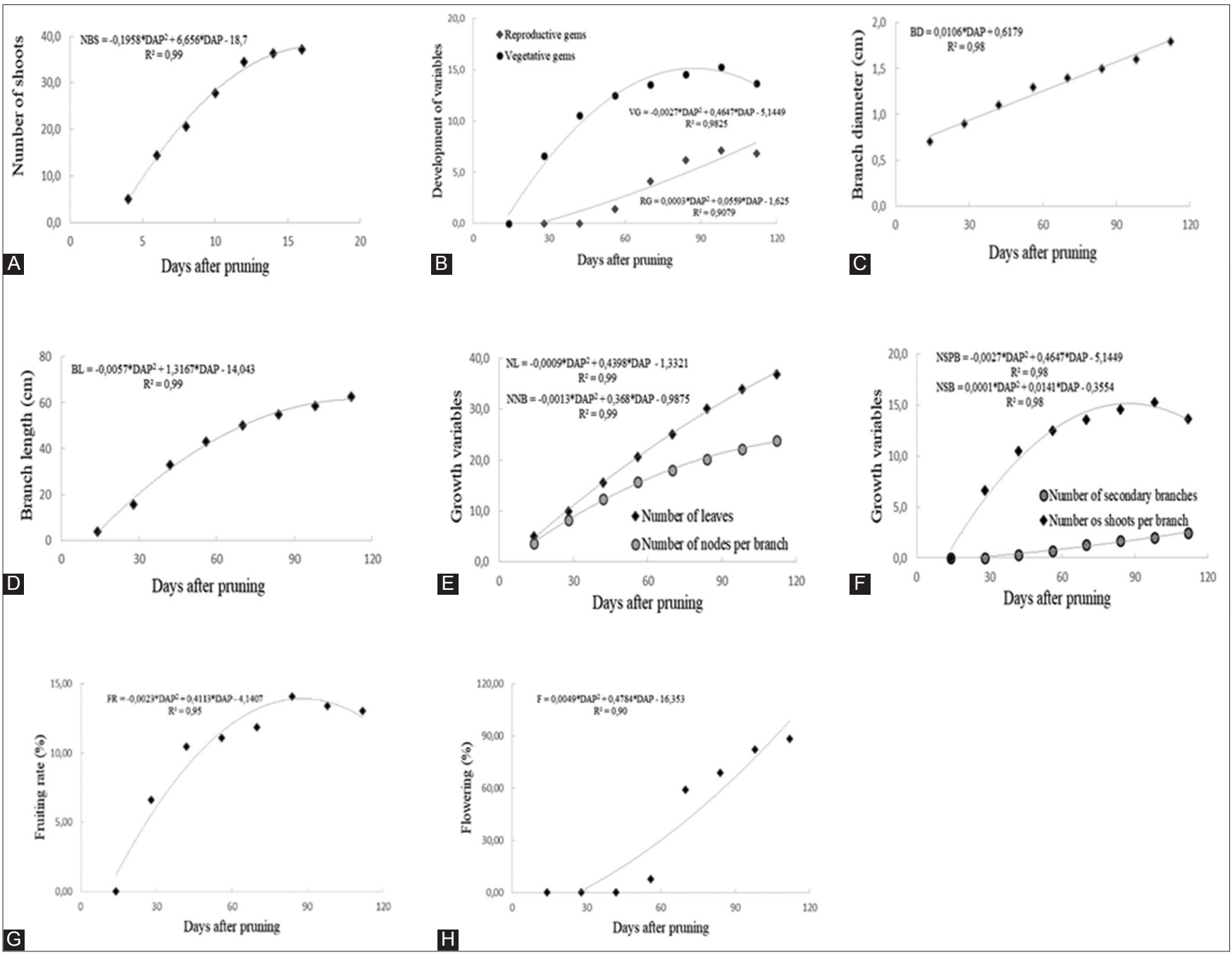

Fig 3. (A) Number of shoots, (B) number of reproductive gems (RG) and number of vegetative gems (VG), (C) branch length, (D) branch diameter, (E) number of leaves (NL) and number of nodes per branch (NNB), (F) number of secondary branches (NSB) and number of shoots per branch (NSPB), (G) flowering, and (H) Fruiting rate, of the fig tree, cv "Roxo de Valinhos." 
of Limoeiro do Norte-CE in three growing environments, and reported a stability of 44 leaves per branch at the field level at 90 DAP.

For Morgado et al. (2013), the characterization of the number of leaves is essential for determining the amount of water transpired by the plants. The monitoring of foliar development elucidates the physiological characteristics associated with plant growth, photosynthetic relationships, and transpiration processes since the leaves are the main organs responsible for photosynthesis.

The number of secondary branches and shoots per secondary branch (Fig. 3F) showed a polynomial growth peaking at $110 \mathrm{DAP}$ with the temperature at $30^{\circ} \mathrm{C}$. Thinning of the branches stimulated the emission of secondary branches in the main productive branches, observing the maximum number of 2.5 secondary branches per the main branch.

The emission of secondary branches may be related to the balance of nutritional reserves in the plant at the end of the winter, causing the budding of gems, and growth of small quantities of primary productive branches (Nava et al., 2015). According to Souza et al. (2009), the high temperatures after the pruning provoke an outbreak in the vegetative growth causing a dispute between the photoassimilates.

The number of fruits per branch (Fig. 3G), presented a polynomial increase during the evaluation phase, the first fruits appeared at $49 \mathrm{DAP}$, at the end of the evaluation period the average number of fruits per branch was 6.01 fruits. According to Silva et al. (2016), solar radiation exposure during the experimental period directly affects the variation in the number of fruits.

The rate of fruit appearance was constant up to 84 DAP (Fig. $3 \mathrm{H}$ ) with the abortion of 0.7 fruits per branch on the following days, due to the decrease of the relative humidity of the air as a function of the temperature increase (Fig. 2). Similar data were found by Freitas et al. (2015), in the region of Chapada do Apodi-CE, when evaluating fruits produced under different growing environments.

Climatic conditions affect the crop cycle considering the direct interference in plant phenology, and therefore in the growth phases (Lazreg-Aref et al., 2017). Thus, based exclusively on the variables presented above, the obtained results suggest that the fig tree cv "Roxo de Valinhos" can be cultivated at the production level in domestic and commercial orchards under the soil and climatic conditions of Bom Jesus, Piauí.

\section{CONCLUSION}

The fig tree presented edaphoclimatic adaptability in semiarid regions. The cv "Roxo de Valinhos" showed promising responses to cultivation in Bom Jesus, Piauí.

\section{ACKNOWLEDGMENT}

Foundation for Research Support of the State of Piauí (FAPEPI) for financial support.

\section{Authors' contributions}

Authors contributed equally to this study.

\section{REFERENCES}

Bain, A., L. S. Chou, H. Y. Tzeng, Y. C. Ho, Y. P. Chiang, W. H. Chen, Y. T. Chio, G. Y. Li, H. W. Yang, M. Hossaert-Mckey and F. Kjellberg. 2014. Plasticity and diversity of the phenology of dioecious Ficus species in Taiwan. Acta Oeco. 57: 124-134.

Bergamaschi, H. 2007. Climate as a determinant of plant phenology. In: Rego (Eds.), Phenology: Tool for Conservation, Improvement and Management of Arboreal Plant Resources. Embrapa Florestas, Colombo.

Caetano, L. C. S., A. G. Melo, I. M. Lima and J. A. Ventura. 2012. Technical Recommendations for the Fig Tree Crop. INCAPER, Brazil. Available from: https://www.biblioteca.incaper.es.gov. br/digital/bitstream/item/37/1/Recomendacoes-tecnicas-sobrecultura-figueira.pdf. [Last accessed on 2019 Jan 04].

Celedonio, C. A., J. F. Medeiros, F. L. Silva, K. L. Saraiva and A. H. P. Alburquerque. 2013. Growing biofertilized (by fertigation) common fig in three cultivation area. Rev. Bras. Agric. Irrig. 7: $358-370$.

Chiang, Y. P., A. Bains, W. J. Wu and L. S. Chou. 2018. Adaptive phenology of Ficus subpisocarpa and Ficus caulocarpa in Taipei, Taiwan. Acta Oeco. 90: 35-45.

Freitas, R. N. S., P. A. Souza, M. E. T. Silva, F. L. Silva and P. B. Maracajá. 2015. Description post-harvest of figs (Ficus carica L.) produced under protected cultivation and open skies the Apodi Plateau CE. Rev. V. Agro. Des. Sust. 10: 43-46.

Gaaliche, B., I. Zarrouk and M. Mars. 2017. Agro-phenological behavior of several caprifigs grown in two different ecological areas in Tunisia. Acta Hortic. 1173: 149-156.

INMET. 2018. National Institute of Meteorology. Available from: http://www.inmet.gov.br/sonabra/pg_dspDadosCodigo_sim. php?QTMyNg. [Last accessed on 2019 Jan 04].

Köppen, W. and R. Geiger. 1928. Climates of the Earth. Verlag Justus Perthes, Gotha.

Lazreg-Aref, H., F. Zaouay, M. Hammami and M. Mars. 2017. Fig fruit latex yield and protease activity as influenced by cultivar, maturity stage and harvesting time. Acta Hortic. 1173: 323-328.

Lopes, P. R. C., I. V. M. Oliveira, R. R. S. Silva-Matos and Í. H. L. Cavalcante. 2013a. Growing Princesa apples under semiarid conditions in Northeastern Brazil. Acta Sci. Agric. 35: 93-99.

Lopes, P. R. C., I. V. M. Oliveira, R. R. S. Silva-Matos and Í. H. L. Cavalcante. 2013b. Phenological characterization of pear trees "Housui" and "Kousui" under semiarid conditions in the Northeastern Brazil. Rev. Bras. Frutic. 35: 105-110.

Lopes, P. R. C., I. V. M. Oliveira and R. R. S. Silva-Matos. 2018. 
Temperate climate fruit crops in the Brazilian semi-arid. In: PIO, (Eds.), Cultivation of Temperate Fruit Trees in Subtropical and Tropical Regions. Editora UFLA, Lavras.

Miranda, J. O. O., I. H. F. Cavalcante, I. V. M. Oliveira and P. R. C. Lopes. 2015. Advances on apple production under semiarid climate: N fertigation. Emir. J. Food Agric. 27: 744-748.

Mezzalira, E. J., A. L. Piva, G. A. Nava, D. Paulus and A. Santin. 2015. Rust and fig tree borer control by different fungicides and insecticides. Rev. Ceres. 62: 44-51.

Micheloud, N., J. C. Favaro, D. Castro, M. Buyatti, M. A. Favaro, M. S. Garcia and N. Gariglio, 2018. Fig production under an intensive pruning system in the moist central area of Argentina. Sci. Hortic. 234: 261-266.

Morellato, L. P. C., M. G. G. Camargo and E. Gressler. 2013. A review of plant phenology in South and Central America. In: Schwartz, M.D., (Eds.), Phenology: An Integrative Environmental Science. Springer, Neederlands.

Morgado, M. A. D., C. H. Bruckner, L. D. S. Rosado, W. Assunção and C. E. M. Santos. 2013. Estimation of leaf area by nondestructive method using linear measurements of leaves of Passiflora species. Rev. Ceres. 60: 662-667.

Nava, G. A., J. Santin, V. B. Vanderson, and D. Paulus. 2015. Branch pruning influences on the production and quality of fig "Roxo de Valinhos". Rev. C. Agro. 14: 29-37.

Oliveira, L. E. M., A. C. Mesquita and E. B. Freitas. 2002. Analysis of Plant Growth. Plant Physiology, Lavras, MG, pp. 1-9.

Oliveira, I. V. M., P. R. C. Lopes and R. R. S. Silva-Matos. 2015.
Phenology evaluation of "Triumph" pear trees grown in semi-arid climate in the Northeast Brazil in 2012 season. Rev. Bras. Frutic. 37: 261-266.

R Core Team. 2018. R: A Language and Environment for Statistical Computing. R Foundation for Statistical Computing, Vienna, Austria. Available from: https://www.R-project.org. [Last accessed on 2018 Nov 10].

Rodrigues, D. N. B., T. V. A. Viana, A. B. Marinho, T. T. S. Ferreira, B. M. Azevedo and R. R. Gomes Filho. 2012. Fertirrigation potassica in the culture of the fig in semiárido from Ceará. Rev. Bras. Agric. Irrig. 6: 176-183.

Santos, H. G. 2013. Brazilian System of Soil Classification. National Soil Research Center, Rio de Janeiro, RJ.

Silva, F. L., T. V. A. Viana, G. G. Sousa, S. C. Costa and B. M. Azevedo. 2016. Yield of common fig fertigated with bovine biofertilizer in the semiarid region of ceará. Rev. Caat. 29: 425-434.

Silva, F. S. O., E. C. Pereira, V. Mendonça, R. M. Silva and A. A. Alves. 2017. Phenology and yield of the "Roxo de Valinhos" fig cultivar in Western Potiguar. Rev. Caat. 30: 802-810.

Souza, A. P., A. C. Silva, S. Leonel and J. F. Escobedo. 2009. Basic temperatures and thermal sum for the fig trees pruned in different months. Rev. Bras. Frutic. 31: 314-322.

Taiz, L., E. Zeiger, I. M. Moller and A. Murphy. 2017. Physiology and Plant Development. Artmed, Porto Alegre, Brasil.

Zhao, T. T., S. G. Compton, Y. J. Yang, R. Wang and Y. Chen. 2014. Phenological adaptations in Ficus tikoua exhibit convergence with unrelated extra-tropical fig trees. Plos One. 9: 1-17. 